\title{
Affirmation without End: Some Syntactical Similarities between the Poetry of Yves Bonnefoy and the Philosophy of Jean-Luc Nancy
}

\author{
Emily McLaughlin
}

$\mathrm{S}$ INCE HE CAME TO PROMINENCE with the publication of Du mouvement et de l'immobilité de Douve in 1953, Yves Bonnefoy has always been quick to affirm the value and the function of poetry. Whether writing about his own work or the work of others, whether writing essays, poetry or prose, he reminds us that poetry's function is affirmative. Poetry is presented as an ontological act, an affirmation of the sense of existence, and a quest to affirm the physical and embodied reality of "la présence" within language. In "L'acte et le lieu de la poésie," published in L'improbable in 1959, the poet insists that the "destin privé de chaque œuvre" is to "donner un sens à ce qui est." The poet continues, "je ne crois pas que soit de poésie vraie que ne cherche aujourd'hui, et ne veuille chercher jusqu'au dernier souffle, à fonder un nouvel espoir" (Bonnefoy, L'improbable 122-23).

It is therefore no surprise that Bonnefoy's writings are dotted with simple affirmative statements, statements that use the verb "être" to affirm the existence of a phenomenon and then provide a simple definition of it. Bonnefoy writes in the early seminal essay "Les tombeaux de Ravenne, "L'objet sensible est présence" (Bonnefoy, L'improbable 26); "Simplement, [le monde] est avec nous. Dans le sensible" (Bonnefoy, L'improbable 28). In an essay on Paul Valéry, he affirms, "La poésie comme l'amour doit décider que les êtres sont" (Bonnefoy, L'improbable, 101). In a more recent essay on Christian Dotremont, published in 2010, he affirms, "la vie est une réalité ultime, enracinée si profond dans l'être qu'elle s'y obstine en dépit de tous les obstacles, qu'elle est donc comme telle la vérité, mais une vérité âpre, "rugueuse." "2 As his use of the word "rugueuse" here suggests, Bonnefoy conceives of this act of affirmation in Rimbaldien terms. The poet is the one who affirms "la réalité rugueuse à étreindre," in all its irreducibility and ungraspability. ${ }^{3}$ And he does so, over and over again.

Critics have been quick to discern the provocative or resistant nature of Bonnefoy's affirmations. Roland Gérard Giguère and Michèle Finck have highlighted how Bonnefoy's affirmative poetics advertise his fidelity to material reality or embodied experience, ${ }^{4}$ at a time when writers and critics are increas- 
ingly preoccupied with the modalities of linguistic production, the ways in which language forms our perception and experience of reality. With the emergence from the 1950s onwards of structuralism and post-structuralism, and literary and psychoanalytic strains of theory, Bonnefoy's simple affirmations seek to counter what he describes as "un parti pris des mots" (Bonnefoy, Le siècle 174). The poet affirms the primacy of presence, the real, and the world. He affirms the sense of words that Heidegger and then Derrida place scrupulously under erasure, words that according to a logic of différance are irretrievably spaced and suspended. At a time of growing artistic and critical skepticism, Bonnefoy's affirmations appear to be defiantly or even willfully naive.

Yet Bonnefoy's affirmations are so striking precisely because they are so effusive. An initial affirmation - "Le sensible est une présence," for exampleoffers a definition that is simple and persuasive, assuaging a basic human need for clarity and identity. This definition then tends to be supplemented by an appositional syntax that repeatedly equates one term with another. The more enthusiastic the poet's affirmations grow, the more they tend to spill, from one clause to another, in a long series of appositions, parataxes or parentheses. The poet's effusively affirmative syntax thus voids processes of definition. Bonnefoy affirms the existence of phenomena that cannot be defined, measured or signified. And whilst the words that he affirms are not erased, as they are in Heidegger's or Derrida's writings, they are nonetheless revealed to be inherently elusive or excessive. Bonnefoy writes, "Le sensible est une présence, notion quasi déserte de tout sens, notion à jamais impure selon l'esprit conceptuel: il est aussi le salut" (Bonnefoy, L'improbable 26).

An important comparison can be drawn between the effusively affirmative syntax of Bonnefoy's writings and the affirmative syntax that we find in the deconstructive philosophy of Jean-Luc Nancy. In the essay, "L'offrande réservée," Alain Badiou writes:

Le style très particulier de Nancy est un style entièrement affirmatif, tout bâti autour d'équivalences signalées par le verbe 'être'. L'énoncé matriciel de Nancy est très simple, c'est une équation du type: ceci est cela. [...] La très grande sophistication de l'écriture [...] tient de ce qu'il faut faire venir la simplicité des équations dans un contexte persuasif d'une douce insistance, d'une invocation presque irrésistible. Et cette pression, cette invocation, organisent simultanément la nécessité de l'identité, 'ceci n'est autre que cela,' et aussi son caractère toujours énigmatique, encore toujours à re-penser. ${ }^{5}$

Badiou suggests that Nancy's ebullient affirmations define one phenomenon in terms of another: "ceci est cela." They persuade us of the necessity of identity or sense, and then they accumulate with "une douce insistance," "une 
invocation presque irrésistible." This accumulation leads to a process of redefinition, a longer series of equations between terms, that makes the phenomenon that is affirmed "toujours énigmatique, encore toujours à re-penser."

This article refutes the idea, most strenuously defended by John E. Jackson, that Bonnefoy's profoundly affirmative poetry directly opposes the central tenets of deconstructive thought. Deconstruction, Jackson writes, is a "[m]ouvement qui heurte de front l'horizon de l'œuvre de Bonnefoy."” Analyzing the similarities that exist between Bonnefoy's and Nancy's affirmative syntax, this article investigates how both the poet and the philosopher cultivate a practice of affirmation that is at once affirmative and deconstructive, thereby transforming traditional conceptions of definition, value, and identity. It proposes that Bonnefoy's affirmative poetics are better conceived as an advancement or development in deconstructive thought. ${ }^{7}$ This is, of course, an advance that Bonnefoy was formulating from 1953 onwards, prior to the emergence even of Derrida's first publications. It is an advance that is glimpsed in sequences of poems such as "Théâtre" in Du mouvement de l'immobilité de Douve in 1953 and which comes fully to fruition with the publication of Dans le leurre du seuil in 1975, the collection of poetry in which Bonnefoy fully commits himself to a finite thinking of the poetic act.

It is perhaps this movement beyond deconstruction, even as deconstruction was emerging, even in the 1950s, that has made it difficult to discern the exact nature of Bonnefoy's relationship to the movement. The emergence of Nancy's deconstructive or post-deconstructive writings from the 1970s onwards, however, makes the nature of this development much easier to discern. Nancy is a deconstructive thinker who shifts the emphasis away from negative textual practices towards processes of affirmation. He affirms the sense of words such as "la présence," "l'être," "le réel," "l'existence," "l'immédiat," "la vérité," "l'ontologie." In works such as L'oubli de la philosophie (1986), Une pensée finie (1990), Le sens du monde (1993), and Etre singulier pluriel (1996) Nancy elaborates a finite thinking of sense. He affirms the sense of the finite act of relation by which we enter into contact with "l'être" or "le réel" and the sense of the temporal and spatial dynamics that endlessly disperse these presences. He elaborates an ontology that is founded on nothing more originary or stable than the fleeting act of relation itself. In Nancy's philosophy, affirmation thus becomes a means of affirming the existence of that which exceeds definition. It becomes an act that demonstrates that value resides, not in any one word or essence, but in the finite gesture of relation itself, what Nancy describes as "le retranchement d'une singularité dans son affirmation de l'être: une touche de sens." 
It is of course important that we remain alert to the note of resistance or provocation that is audible in Bonnefoy's affirmations. Bonnefoy does feel that twentieth-century deconstruction has been too single-mindedly devoted to negative textual practices or that critique has been privileged at the expense of, and even to the exclusion of, affirmation. Such an attitude, he warns in his inaugural lecture at the Collège de France as he assumes the chair previously occupied by Barthes, "s'accompagne d'un risque de décomposition et de mort pour la société tout entière." ${ }^{.}$Yet if Bonnefoy virulently rejects a practice of deconstruction for its own sake, he accepts the revelations that it makes about the dissemination of meaning within language. ${ }^{10} \mathrm{He}$ accepts the emphasis that it places upon the dynamism and singularity of experience. What Bonnefoy calls for-much like Nancy—is a change in emphasis, a greater equilibrium between practices of deconstruction and practices of affirmation. He asks us to imagine the affirmative gesture that survives "la déconstruction de l'antique visée ontologique" (Bonnefoy, Entretiens 186). He asks us to consider the kind of presence, sense or identity that might persist in a temporally and spatially dispersed world. He insists that if writing has a duty to enact a salutary process of deconstruction - the archetypal example of which, for Bonnefoy, is Mallarmé's experience of "le néant"-it is only in order to affirm a newly mobile and finite thinking of human relation.

Certainly, in this quarrel between affirmative and critical modes of thought, it is the question of language's finite act of relation with the physical world that is at stake. Bonnefoy insists that the function of poetry is to affirm the existence of beings or presences that exceed linguistic structures and to engage with them, tentatively, fleeting, in their excess. This, for Bonnefoy, is the essence of poetic agency. The poet affirms a fleeting act of relation with "le réel" and initiates a certain mode of being in the world. The poet's reservations about movements such as Derridean deconstruction are due to the way in which they inhibit this kind of engagement: its predominantly critical and self-reflexive texts remain focused on the limitations of signification, refusing to affirm that which cannot be signified and questioning language's ability to enter into relation with an exterior reality. For Bonnefoy, such critical work within language must always pave the way for an engagement with and an affirmation of forces beyond language. Therein lies poetry's capacity for contact and exchange. Without it, Bonnefoy insists, the poetic act is deprived of its ontological and ethical force, its philosophical and political importance.

The affirmative nature of Nancy's philosophic project is perhaps best revealed in Etre singulier pluriel (1996), a text that asserts the primacy of relation and affirms the sharing of existence as "le sens." Refusing to conceive 
of sense in abstract or conceptual terms, the philosopher affirms a sense that existence no longer has but that existence in itself is. One can immediately see how, as Badiou suggests, the affirmative equation "ceci est cela" functions as the "énoncé matriciel" of this thinking of sense. Etre singulier pluriel is dotted with such affirmations and they are supplemented by long series of reformulations, as the poet breaks into an appositional and paratactic syntax. Nancy writes, for example:

Nous faisons sens: non pas en conférant du prix, de la valeur, mais en exposant le valoir absolu que le monde est par lui-même. 'Monde' ne veut dire rien d'autre, rien que ce 'rien' que nul ne peut 'vouloir dire,' mais que tout dire dit: l'être même comme valoir absolu en soi de tout ce qui est: mais ce valoir absolu comme l'être-avec de tout ce qui est, lui-même nu et inévaluable. Ni vouloir-dire, ni dire-valoir, mais la valeur en tant que telle, c'est-à-dire 'le sens' qui n'est celui de l'être que parce qu'il est l'être lui-même: son existence, sa vérité. Or l'existence est avec: ou bien rien n'existe. (Nancy, Être 22)

Nancy begins by affirming the sense that we make, the sense that we ourselves are. A colon ensues, and this affirmation is then subject to a lengthy process of redefinition. The initial positive statement is recast in negative terms. This sense is not a value that is extractable from existence but that is, rather, consubstantial with existence. We make sense because we exposeand here Nancy makes an important equation - "le valoir absolu que le monde est par lui-même." Nancy affirms a long series of terms, "nous," "le sens," "le valoir absolu," "le monde," by equating one continually with another and by voiding traditional processes of definition.

Value and sense are thus affirmed as "rien." They collapse into embodied and material existence, becoming meaningless in a traditional sense: “'Monde' ne veut dire rien d'autre, rien que ce 'rien' que nul être ne peut 'vouloir dire." Yet, in the very same gesture, value and sense become excessively meaningful. They are affirmed as "tout": "ce 'rien' que nul être ne peut 'vouloir dire,' mais que tout dire dit: l'être même comme valoir absolu en soi de tout ce qui est." Value becomes all and nothing, something omnipresent and yet ungraspable. It is absolute, Nancy suggests, not because it is in any way autonomous or essential, but because it is absolutely shared, absolutely dispersed: "ce valoir absolu comme l'être-avec de tout ce qui est, lui-même nu et inévaluable."

Nancy's affirmations dissolve into a long series of appositions and parataxes. One term is equated to another, and another: affirmation becomes an appositional dynamic. We affirm a sense, which is the world, which is value in itself, which is being, which is being-with. We move horizontally 
within language, circulating between apposite terms. The nouns "le sens," "le valoir" or "le monde" are emptied of any definitive value and are opened up to the shared value of all that $i s$. And the appositional syntax keeps running, affirmations keep coming, for, as Nancy writes, "l'existence est avec: ou bien rien n'existe."

A very similar form of affirmative syntax manifests itself in Bonnefoy's critical essays. The poet often makes an important affirmation, using the form of equation that Badiou identifies in Nancy's writings, "ceci est cela," and then elaborates a set of appositional reformulations. Consider, for example, the important early affirmation of "la présence" that Bonnefoy makes in "Les tombeaux de Ravenne":

L'objet sensible est présence. Il se distingue du conceptuel avant tout par un acte, c'est la présence.

Et par un glissement. Il est ici, il est maintenant. Et son lieu, parce qu'il n'est pas le lieu propre, son temps, parce qu'il n'est qu'un fragment du temps, sont les éléments d'une force étrange, d'un don qu'il fait, sa présence. Ô présence affermie dans son éclatement déjà de toutes parts! Dans la mesure où il est présent, l'objet ne cesse pas de disparaître. Dans la mesure où il disparaît, il impose, il crie sa présence. (Bonnefoy, L'improbable 26)

Bonnefoy affirms that the perceptible object is "[une] presence." Shifting, as Nancy does, between positive and negative modes of definition, he suggests that this "objet sensible" will not be the object of conceptual thought because it is "un acte," which is to say, "la presence." The temporal and spatial dynamics of this act-its "glissement" "ici" and "maintenant"- are then defined in another series of appositional terms as its "force étrange," its "don," its "présence." The poet then slips into a series of paradoxical formulations, apostrophizing a phenomenon whose force is intensified by its very dispersal, a force that we can feel slipping away as it presents itself or presenting itself as it slips away. Bonnefoy's effusive affirmations, spilling from one clause to the next, affirm presence's inherently excessive force, a dynamism and a fleetingness that will not be subject to definition or conceptualization.

The appositional nature of Bonnefoy's affirmative syntax is more pronounced in his poetic writings. Verse perhaps gives the poet more freedom to accumulate appositional clauses. Dans le leurre du seuil (1975) is the collection of poetry in which sentences most frequently break down into long series of reformulations or even simply long lists of phenomena. Bonnefoy's most formally elaborate collection of poetry, it is written as one long poem that is divided into seven titled poems, which are in turn broken down into smaller poems by a series of dotted lines. ${ }^{11}$ Heavily influenced by the oral rhythms of 
liturgy, this collection is rhythmic in its inception. It is structured around a series of pseudo-refrains, as certain prepositions and verbs are repeated at regular intervals at the beginning of stanzas. One of the over-arching themes of the collection is the fleeting nature of the act of relation. "Dans le leurre du seuil," for example, is a meditation on the ephemeral gesture of communication; "Deux barques" explores the way in which water endlessly slips from the human hand; "La terre" dramatises the movement by which the human hand reaches for the other and must always keep reaching. This profoundly rhythmical collection of poetry thus offers a rhythmical thinking of presence, sense, identity, and ethics. Presence or sense or human coexistence is affirmed through the endless repetition of fleeting acts of relation.

A poem at the centre of "La terre" is structured around the refrain "Retrouvons-nous." ${ }^{12} \mathrm{An}$ address to a lover and a plea for intimacy, this poem is also a meditation on the nature of human togetherness, on its transience and its intermittence, its value and its sense. Throughout the poem, the poet's calls for a shared presence or identity are constantly countered by the dispersive dynamic of an appositional syntax. Ultimately affirmation is embraced in precisely these terms, as a transient and effusive motion. In the opening lines of the poem, the lovers' union is envisaged as a high and luminous encounter, an ecstatic outpouring. This image suggests the paradoxical nature of the poet's yearning for a shared presence or identity. He seeks to have it, even though he experiences it as pure motion:

\section{Retrouvons-nous}

Si haut que la lumière comme déborde

De la coupe de l'heure et du cri mêlés,

Un ruissellement clair, où rien ne reste

Que l'abondance comme telle, désignée.

The poet uses a zeugma, "la coupe de l'heure et du cri," to present the passing of time and cries of sexual pleasure as part of the same dynamic. They are both the endless overspilling of a "ruissellement clair," a movement suggested by the way that the verb "déborde" spills over the line end in an enjambment. This is a motion, Bonnefoy suggests with another enjambment, that holds nothing in reserve: "rien ne reste / Que l'abondance comme telle, désignée." Nothing is kept, but existence is revealed in its endless expenditure, in its excess.

As the poet reissues his appeal, repeated plosive alliterations reinforce the physicality of his desire: "Retrouvons-nous, prenons / À poignées notre pure présence nue." The cohortative "prenons" falls at the line end, and this suspension of the object of desire intensifies the sense of longing. The poet longs 
to take possession of the "nous," of this shared physical presence, as if it were one entity or essence. This appropriative and essentialist desire, however, finds itself dispersed over a long series of appositions:

Retrouvons-nous, prenons

À poignées notre pure présence nue

Sur le lit du matin et le lit du soir,

Partout où le temps creuse son ornière,

Partout où l'eau précieuse s'évapore.

Portons-nous l'un vers l'autre comme enfin

Chacun toutes les bêtes et les choses,

Tous les chemins déserts, toutes les pierres,

Tous les ruissellements, tous les métaux.

These appositional formulations present presence as an endless passage, a passage that necessitates an endless repetition of acts of possession, "Sur le lit du matin et le lit du soir." Reiterative sentence structures and sound effects enact this repetition. Everywhere time hollows its rut and disperses presence; everywhere, one being must reach out to another. The poet can only make renewed entreaties: "Portons-nous l'un vers l'autre." There is a subtle interplay between the fricative alliteration of "chacun"- taken up in "chemin" and "choses" - and the dental alliteration repeated in "tous" and "toutes": "Chacun toutes les bêtes et les choses, / Tous les chemins déserts, toutes les pierres, / Tous les ruissellements, tous les métaux." Bonnefoy counterpoints the singularity of the individual act, by which "chacun" reaches out to another, and the endless proliferation of these singularities, repeated by "tous," by "toutes," everywhere.

An appositional syntax enacts the dispersal of presence. The appearance of an isolated imperative then functions as a kind of volta, allowing the poet to make an important equation:

Regarde,

Ici fleurit le rien; et ses corolles,

Ses couleurs d'aube et de crépuscule, ses apports

De beauté mystérieuse au lieu terrestre

Et son vert sombre aussi, et le vent dans ses branches,

"[La] présence" is equated with "le rien." This presence which is a nothingness flourishes, and the appositional syntax suggests this efflorescence. It blossoms forth in insistent sibilant and velar alliterations: "ses corolles, / Ses couleurs d'aube et de crépuscule." Like colour's endless gradations, played out against the dawn and the dusk sky, it takes endlessly different forms from 
one clause to the next. This constant formation and dissolution produces "ses apports / De beauté mystérieuse." If this presence is mysteriously beautiful, it is because it dissolves, because it is illimitable. Bonnefoy uses the colour green, or the wind that moves in the greenery, or the echo of sounds between the words "vert" and "vent" to suggest this undefinability. Presence, like nothingness, like beauty, is endlessly productive and endlessly ungraspable.

The stanza ends with an important affirmation. Of this presence, which is nothingness, which is beauty, the poet affirms, "C'est l'or qui est en nous." The poet uses the traditional symbol of worth to affirm the value of presence and then breaks into an appositional syntax that empties this symbol of all traditional conceptions of value:

C'est l'or qui est en nous: or sans matière,

Or de ne pas durer, de ne pas avoir,

Or d'avoir consenti, unique flamme

Au flanc transfiguré de l'alambic.

Each negative epithet refuses a conception of value as something substantial, appropriable, and preservable. Each suggests that what is valuable slips away. Value is the "unique flamme / Au flanc transfiguré de l'alambic." This final image rejects the traditional conception of poetry as an alchemy that distils worth and emphasises instead a singular and ephemeral burning: the "unique flamme" that heats the side of the alembic. Bonnefoy suggests that value is exposed - the poem's value, the value of existence - not through a process of extraction but through a process of expenditure. Value is displayed in the poem's own finite gesture, in the motion by which it too flares and dissipates.

In the final two stanzas of the poem, this meditation on the nature of value becomes a meditation on the nature of divinity, this ultimate signifier of worth. Together, the two final stanzas constitute one logically argued sentence. The first line of the second stanza presents the main clause, and the first line of the third stanza presents the sub-clause: "Et tant vaut la journée qui va finir / [...] Que tu peux nommer Dieu ce vase vide." Across the two stanzas, however, these two clauses are repeatedly paraphrased. As the poet stresses the worth of finite existence, he breaks into an appositional syntax that celebrates the value of each instance in its singularity. The deductive and definitional logic of the sentence gives way to a simple process of enumeration: "Et tant vaut la journée qui va finir, / Si précieuse la qualité de cette lumière, / Si simple le cristal un peu jauni / De ces arbres, de ces chemins parmi les sources." The poet stresses the worth of a gradation of light, a certain tint in the glass, a particular distribution of space. Each image rises and falls. It 
passes, the particularity of its detail charged with the poignancy and the pleasure of its passing.

The final stanza asserts that this dynamic that holds nothing in reserve, "ce vase vide," can be named "Dieu." Echoing Mallarmé, Bonnefoy suggests that finitude gives existence its divinity. ${ }^{13}$ Echoing Hölderlin, he suggests that the divine persists in a finite world as a passing. ${ }^{14}$ Using the proper noun with its capital letter to denote transcendent value, "Dieu," Bonnefoy suggests that finitude gives existence its entire worth. Yet, like the gold that was neither appropriable nor preservable, this is a God who does not exist: "Dieu qui n'est pas, mais qui sauve le don, / Dieu sans regard mais dont les mains renouent, / Dieu nuée, Dieu enfant et à naître encore, / Dieu vaisseau pour l'antique douleur comprise." If finitude gives existence its entire value, it is not because it is the transcendental value of existence. It is because finitude's endless motion voids transcendental value and, in doing so, restores value to the dynamics of earthly existence: the formation of a cloud, the birth of a child. The motion of finitude is thus the motion into which the divine withdraws. As Nancy writes of Hölderlin's poetry: "[1]e divin est le passage, et n'est que ça" (Nancy, Calcul 75).

This dispersive motion into which God retreats is suggested by the recurrent images of empty forms in the final stanza, "vase vide," "vaisseau," "voûte." These words all begin with the letter "v," itself another empty container, and the same form appears, inverted, above the word "voûte," the circumflex rising above the word in an arch: "Dieu voûte pour l'étoile incertaine du sel / Dans l'évaporation qui est la seule / Intelligence ici qui sache et prouve." Bonnefoy uses the image of the arch of evaporation, much as he uses the image of the alembic in the first stanza, to deconstruct the notion that value resides within an essence or extract. What is valuable, Bonnefoy suggests, is not salt's deposit, the traditional symbol of worth and divinity, but the motion of evaporation itself: a dynamic rather than an essence, a dispersal rather than a deposit. Presenting evaporation as "la seule / Intelligence ici qui sache et prouve," Bonnefoy locates intelligence - the force that traditionally confers value, that authenticates and proves - neither above nor outside existence. Only the motion of existence itself, Bonnefoy suggests, affirms the reality or the identity or the value of existence. Existence can be authenticated or validated only by its own dynamics.

"Retrouvons-nous" affirms the value of intermittent and dispersed experiences of intimacy or identity, the value of a presence that dissolves and retreats into nothingness. It presents this motion as "la valeur en tant que telle," to use Nancy's formulation. Affirmation thus becomes an ephemeral 
dynamic: the repeated reaching motion by which one lover goes towards the other; the poet's repeated embrace of singular moments of experience. It becomes a fleeting, and thus repetitive or effusive, act of relation. The final poem of Dans le leurre du seuil, "L'épars, l'indivisible," is structured around the refrain "Oui, par": this formulation introduces diverse images of people and things, concrete and abstract phenomena, quotidian and creative gestures. Like "Retrouvons-nous," this poem presents affirmation as a means and not an end, as the act by which we go towards the things of the world, over and over again. Bonnefoy writes: "Oui, par la cime éclairée / Une heure encore" (Bonnefoy, Poèmes 319); "Oui, par les mots, les quelques mots" (Bonnefoy, Poèmes 327); "Oui, par la main que je prends / Sur cette terre" (Bonnefoy, Poèmes 329). Affirmation becomes this refrain, this rhythm: a process without end, synonymous with living, desiring, speaking or reaching, an engagement with presence and absence, everything and nothing.

The effusive nature of Bonnefoy's and Nancy's affirmations allows us to perceive the similarities that exist between between Bonnefoy's thinking of the passage of "la présence" and Nancy's thinking of "le sens" in its singular plurality. Both the poet and the philosopher protest that a sense is present here - in us, in material presence, in all that is - that we have neglected by lamenting the death and the loss of sense. They conceive of sense as something consubstantial with existence, something fleeting, contingent, and effusive. And in response to this sense, their practice of affirmation becomes effusive too. The poet and the philosopher thus affirm one thing by equating it to another. A simple definition, "L'objet sensible est une présence," initiates a sequence of equivalences that void or exhaust all possibility of definition. The noun-whether it be "le sens," "le valoir," "la présence," "l'or" or "Dieu"is emptied of its transcendental value, and value is allowed to circulate between words. Just as the withdrawal of God restores value to the dynamics of finite terrestrial existence, so the dispersal of the transcendental value of the noun restores value to the movement of the phrase. Ephemeral movement is validated. Value is conceived in transitive terms, as a force shared and spent in the act of relation.

Both Bonnefoy and Nancy remind us that value circulates, not only in the movement of the phrases, but in the ordinary gestures of everyday life. They insist that, whilst beauty, sanctity and sense are no longer forces that we might contain or confer using language, essences to which we might accede, they are still available to us. Here and now, in the present moment, there is a beauty, sanctity or sense that is given effusively, that invites us endlessly to attend to its passing. Affirmation, Nancy writes in Etre singulier pluriel, surrenders 
itself to this passage of presence: "passant elle-même avec elle," "abandonnée dans son mouvement même" (Nancy, Etre 22). Affirmation is the act that seeks to participate in or share "le sens qui n'est celui de l'être parce qu'il est l'être lui-même" (Nancy, Être 7). These forces are available, of course, only when we allow them to remain fleeting, dynamic, and contingent. This is the philosophical or political imperative that emerges from Bonnefoy's poetry. We have a responsibility to keep value shared, to keep language open to this sharing. Over and over again, we must open up the inherently essentialist and appropriative signifying structures of language to the temporal and spatial dynamics of existence and the contingency of the finite act of relation. We must keep our affirmations effusive, which is to say, always open to the next affirmation, and the next, and the next.

In precisely these terms, Dans le leurre du seuil is Bonnefoy's most affirmative collection of poetry. It is the collection that most readily surrenders language to rhythm, and sense to movement. Acts of address are ventured and endlessly repeated. Affirmations are dispersed across apposite clauses, refrains or lists. Desire - whether it is for a desire for contact, identity, beauty or sense-is the collection's endless refrain. This desire allows itself to be endlessly consumed and endlessly reborn. Its performance is the burning of the ephemeral flame evoked in "Retrouvons-nous." This performance is ontological, not because it engenders a sense, but because, as Nancy writes, "[elle] s'engendre comme l'acte et dans l'acte d'être-au-monde et d'être-monde" (Nancy, Etre 7). It affirms a sense that is an act, a rhythm, a refrain. "Oui," Bonnefoy writes:

Oui, par la mort,

Oui, par la vie sans fin.

Par hier réincarné, ce soir, demain,

Oui, ici, là, ailleurs, ici, là-bas encore. (Bonnefoy, Poèmes 330)

The Queen's College

Notes

1. Yves Bonnefoy, L'improbable (Paris: Gallimard, 1983), 122.

2. Yves Bonnefoy, Le siècle où la parole a été victime (Paris: Mercure de France, 2010), 117.

3. Arthur Rimbaud, Euvres complètes (Paris: Gallimard, 2009), 116.

4. Giguère writes that Bonnefoy affirms "la précellence du monde sensible extérieur" (Roland Gérard Giguère, Le concept de la réalité dans la poésie d'Yves Bonnefoy [Paris: Nizet, 1985], 124). Finck suggests that Bonnefoy's poetry "s'ouvre au réel et se confond avec lui" (Michèle Finck, Yves Bonnefoy, le simple et le sens [Paris: José Corti, 1989], 14). 


\section{L'ESPRIT CRÉATEUR}

5. Alain Badiou, "L'offrande reservée," in Francis Guibal and Jean-Clet Martin, eds., Sens en tout sens: Autour des travaux de Jean-Luc Nancy (Paris: Galilée, 2004), 17.

6. Jackson writes, "Ces années [...] sont [....] les années de l'émergence en France du vaste mouvement de renouvellement des idées auquel ont été accolées les épithètes des 'poststructuraliste,' de 'déconstructionniste' ou de 'post-moderne.' Mouvement qui heurte de front l'horizon de l'œuvre de Bonnefoy. Que ce soit sur le plan de la réflexion picturale ou littéraire ou sur le plan de l'enjeu poétique, la notion centrale que Bonnefoy a essayé à la fois de clarifier et de rendre sensible est la notion de présence. La présence, c'est le mode sur lequel l'unité de l'être ou du monde se révèle, en deçà ou au-delà de la saisie conceptuelle que le langage peut en faire. [...] le propre du langage, du moins dans la perspective structurale ou néo-structurale, serait de rendre illusoire la notion de la présence" (John E. Jackson, À la souche obscure des rêves: La dialectique de l'écriture chez Yves Bonnefoy [Paris: Mercure de France, 1993], 60-61).

7. Arnaud Buchs's Une pensée en mouvement explores the deconstructive nature of Bonnefoy's writings but suggests that these impulses are channelled back into a reconstructive project: "[Bonnefoy] vise à rétablir [la] métaphysique de l'être en tant que présence"; "plus qu'à une déconstruction ontologique, Bonnefoy en appelle littéralement à une reconstruction de l'ontologie" (Arnaud Buchs, Une pensée en movement: Trois essais sur Yves Bonnefoy [Paris: Galilée, 2008], 14). My article argues, on the contrary, that Bonnefoy's affirmative impulse is inherently deconstructive. Far from reconstructing an ontology, the poet encourages us to perceive the necessarily mobile and relational nature of any kind of ontological thought. He encourages us to experience ontology anew, in finite and dynamic terms.

8. Jean-Luc Nancy, Etre singulier pluriel (Paris: Galilée, 2013), 24.

9. Yves Bonnefoy, Entretiens sur la poésie (1972-1990) (Paris: Mercure de France, 1990), 186.

10. Bonnefoy insists that late nineteenth-century poetry, Rimbaud's "Les voyelles" in particular, was already exploring "comment vie et dévie sans fin le signifiant dans les signes" (Yves Bonnefoy, Entretiens, 186).

11. The dotted lines that divide up the seven texts of Dans le leurre du seuil confer a remarkable structural indeterminacy upon the collection. Are these lines to be read as interruptions, similar to stanzaic breaks, or as separations, similar to the breaks between poems? It is impossible to decide. All the poems of Dans le leurre du seuil can thus be conceived either as part or as whole. It is for this reason that I simply use the word 'poem' to refer to Dans le leurre du seuil, "La terre," or each of the many of sections of "La terre."

12. Yves Bonnefoy, Poèmes (Paris: Gallimard, 1982), 290-91.

13. Stéphane Mallarmé, CEuvres complètes, I (Paris: Gallimard, 1998), 198.

14. Nancy's essay on Hölderlin's poetry, Calcul du poète, examines precisely this notion of the gods' "passage." He suggests that Hölderlin's poetry offers a metre or measure that is "le vestige sensible et exact du passage des dieux, c'est-à-dire de ce passage que sont les dieux" (Jean-Luc Nancy, Des lieux divins, suivi de Calcul du poète [Mauverzin: Éditions T.E.R., 1997], 75). 